\title{
LONG-TERM PERCEPTIONS AND ACTIONS OF THE PUBLIC TO ADDRESS SUSTAINABLE WATER RESOURCE MANAGEMENT IN THE PACIFIC NORTHWEST, USA
}

\author{
ROBERT L. MAHLER \\ Department of Soil and Water Systems, University of Idaho, USA
}

\begin{abstract}
The purpose of this paper is to examine public perceptions and the voluntary actions that have been taken to address the quality and quantity of water resources over a 32-year period in the Pacific Northwest. Mail-based surveys were used to collect data in 1988, 1993, 1998, 2002, 2005, 2007, 2010, 2012, 2015, 2017 and 2019 in the states of Alaska, Idaho, Oregon and Washington. In each survey year, the minimum sample size was 400 adult residents and appropriate statistics were used to evaluate survey answers. Since 1988, a majority of surveyed residents have considered (1) drinking water, (2) wetlands, (3) snowpack, (4) power generation, (5) commerce, (6) industry and (7) aquatic organisms very important. Compared with data initially collected in 1988 (21.6\%), over $92 \%$ of the survey respondents undertook at least one voluntary action to address water quantity such as installing in-home watersaving devices, reducing water use in the home, reducing water use in the yard and/or changing the way vehicles were washed by 2019. Compared with 1988 (16.2\%), over $72 \%$ of the survey respondents took one or more actions to protect water quality by 2019 . Some of these voluntary actions to protect water quality included better disposal of hazardous household and/or yard chemicals, improved use of fertilizers and pesticides in yards, reduction in yard watering practices to reduce chemical leaching or erosion and proper disposal of used automobile/truck oil products. These surveys conducted over a 32-year period show that less than 10 and $8 \%$ of the surveyed public have not taken at least one action to positively address water quantity and water quality issues, respectively. These results are impressive because they show that the public have been engaged in protecting their water resources. Any activity that protects water quality and/or reduces water use makes the water resources of this region, which encompasses more than $26 \%$ of the USA's land area more sustainable.

Key words: public opinion, sustainable water resource management, voluntary actions to protect water, water quality, water quantity
\end{abstract}

\section{BACKGROUND}

The public in the four Pacific Northwest (PNW) states (Alaska, Idaho, Oregon and Washington) considers water resources the most important environmental issue in the region [1]. Since the Clean Water Act was passed by Congress in 1972, laws have been enacted at the federal, state and local levels to address water pollution issues. Researchers have suggested that voluntary actions taken by the public to address water quantity and/or water quality issues may be more effective and better received by the public than addressing water pollution by relying exclusively on regulation. This paper examines some of the voluntary actions taken by PNW residents to address water resource issues $[2,3,4]$.

\section{INTRODUCTION}

Only a small portion of the water in the hydrologic cycle is considered fresh. Humans and the $2,800,000+$ different terrestrial species on planet Earth depend on this freshwater. The human population on Earth exceeded 7,800,000,000 in 2020. Freshwater demands by humans continue to increase because of several factors including the fact that the human population increases by more than $81,000,000$ each year [5]. Humans are dependent on this freshwater supply for drinking, food production, energy production, transportation, ecosystem services 
and recreational purposes. In addition to population growth, lifestyle changes, increasing affluence and climate change have all contributed to the increased demand for freshwater and increased freshwater scarcity $[1,2]$. The protection and preservation of planet Earth's water resources has been a paramount environmental issue in the scientific community for over 50 years.

Countries with high population densities tend to have the biggest challenges to meet water quality and water quantity needs. From a food production standpoint, planet Earth currently produces enough food to adequately feed the population; however, the uneven distribution of food production and poor storage of harvests often result in hunger, malnutrition and famine in certain geographic areas. The world's two most populous countries, China and India with $2,800,000,000$ people, are highly dependent on irrigation water to feed their people. These irrigation systems use both surface and groundwater to grow enough food for their large populations. Unfortunately, this food sufficiency has come at the expense of declining water tables and reduced river flows. In parts of India and China, the overuse of groundwater has resulted in water tables in certain regions falling by more than $20 \mathrm{~m}$ per decade. At some point, unless proactively managed, these groundwater resources will become depleted resulting in the production of less food. This is becoming an increasing problem as more than $3,000,000,000$ will live in these two countries by 2050. Clearly, water resources in China, India and at least 40 other countries with low water supply are unsustainable. Other drier areas of the world including North Africa, Australia, the Middle East, the Aral Sea region and the western USA face similar situations.

There is solid evidence that there is an important link between the quality and quantity of water resources. Declines in groundwater levels often have negative effects on both the quality and quantity of surface waters. In parts of the drier areas of China, irrigation water returns are the most important recharge sources for the declining aquifers [6]. Most of these return flows recharge aquifers with poor quality water that in turn negatively impacts groundwater quality. Studies have shown that agriculture can significantly degrade groundwater quality $[7,8]$.

In many parts of the world, political pressure has been put on governments to protect both surface water and groundwater quality and quantity. Consequently, many governments have resorted to a regulatory approach to protect water resources. In addition to regulations, a groundswell of support for voluntary actions to protect water resources is present in many developed countries [9]. More encouragingly, several studies have shown that a mixed approach - using both regulatory and voluntary actions - by citizens works best [10]. Several political and social scientists have called for voluntary actions, regulatory approaches and economic strategies to be integrated to protect both the quality and quantity of water resources [11]. Some have suggested that a hybrid water conservation policy should integrate and include mandatory restrictions on water use, fines for overuse and pricing increases, which could be a more effective policy than a total voluntary or regulatory approach [12]. The success of such policies to make water resources more sustainable ultimately depends on the involvement of stakeholder groups at the start of the protective effort [13].

An increased emphasis has been placed on public education to support voluntary citizen efforts as a mechanism to improve the USA's water resources since 1987. Because of this new emphasis, a large water education program was begun at this time in the PNW. Surveys have been used to track both public perceptions of water issues and the voluntary actions the public has taken part in. Consequently, the purpose of this paper is to examine public perceptions and the voluntary actions that have been taken to address the quality and quantity of water resources over a 32-year period in the PNW. 


\section{METHODOLOGY}

A survey instrument was developed to access public attitudes about specific water uses and voluntary actions taken by the public to enhance the quality and quantity of water resources in the PNW, USA. The specific questions addressed in this survey study included:

Q-1. How important are each of the following water issues to you? (select-not important, somewhat important, no opinion, important or very important for each item). The water issues surveyed were a. Clean rivers and lakes; b. Clean marine water; c. Preservation of wetlands; d. Clean drinking water; e. Clean groundwater; f. Water for power generation; g. Aquatic habitat; h. Water for recreation; i. Water for mountain snowpack; j. Bays and estuaries; $\mathrm{k}$. Irrigation water for agriculture; 1 . Water for industry and $\mathrm{m}$. Water for commerce.

Q-2 Have you taken an individual voluntary action to protect water quality around your residence? (answers - yes, no, no opinion)

Q-3 If you answered yes to Q-2, check the voluntary activities you took part in to improve water quality:

a. Better disposal of hazardous household/yard wastes

b. Improved use of fertilizer/pesticides in the yard or chemicals in your home

c. Reduction in outside watering practices to prevent chemical leaching or runoff

d. Proper disposal of use automobile/truck used oil products

Q-4 Have you taken an individual voluntary action to protect water resources (water quantity) quality around your residence? (answers - yes, no, no opinion)

Q-5 If you answered yes to Q-4, check the voluntary activities you took part in to improve water resources (water quantity):

a. Installing in-home water-saving devices

b. Reducing water use in the home

c. Reducing outside water use

d. Reducing water use when washing vehicles

The above survey questions were included in all 11 surveys conducted between 1988 and 2019. In 2002, 2007, 2012 and 2017, these questions were embedded into a 60-question surveys that were sent to over 2,500 residents of the region. The same questions were embedded into smaller 30-question surveys that were sent to 1,200 residents in 1988, 1993, 1998, 2005, 2010, 2015 and 2019. Consequently, answers to each of the survey questions were obtained in 1988, 1993, 1998, 2002, 2005, 2007, 2010, 2012, 2015, 2017 and 2019.

The survey target audience was a representative sample of the 11,400,000 adult residents of Idaho, Oregon and Washington that live within the four PNW states. In addition, demographic information, including state of residence, community size, county population, gender, age and educational level were also collected. Community size data were translated into urban, suburban and rural based on the county of residence. Residents were considered urban if they resided in a county (borough in Alaska) with more than 100,000 people. They were considered suburban if they resided in a county with between 30,000 and 100,000 residents. Residents residing in counties with less than 30,000 people were considered rural. Based on census estimates in 2020, there were 28, 34 and 74 counties in the PNW classified as urban, suburban and rural, respectively. 
Table 1: Summary of methodology to evaluate voluntary actions made by the public to protect water quality and water resources (water quantity) between 1988 and 2019 in the PNW.

\begin{tabular}{lll}
\hline Step & Input & Outcome \\
\hline 1 & $\begin{array}{l}\text { Development of questions to determine } \\
\text { voluntary actions taken by the public. }\end{array}$ & Five survey questions \\
2 & $\begin{array}{l}\text { Insert five questions into regional } \\
\text { surveys. }\end{array}$ & This is the instrument used in mailings. \\
3 & $\begin{array}{l}\text { Surveys to be mailed to the public in } \\
1988,1988,1993,1998,2001,2005,\end{array}$ & $\begin{array}{l}7,400 \text { surveys completed by the public } \\
\text { in the 32-year period. }\end{array}$ \\
& $\begin{array}{l}\text { 2007, 2010, 2012, 2015, 2017 and 2019. } \\
\text { Data compiled from each survey. }\end{array}$ & $\begin{array}{l}\text { Data are statistically analysed. } \\
\text { Over time the percentage of residents } \\
\text { taking voluntary actions to protect } \\
\text { water resources greatly increased. }\end{array}$ \\
\hline
\end{tabular}

Each survey was developed using the Dillman methodology and was delivered to clientele via the United States Postal Service [14,15]. A sufficient number of completed surveys were the goal to result in a sampling error of 3 to 5\% [16]. The survey process was also designed to receive a completed survey return rate of more than $50 \%$. Addresses were obtained from a professional social sciences survey company (SSI, Norwich, CT). Four mailings were planned to achieve the $50 \%$ return rate. The mailing strategy used was identical in all 11 surveys that had been conducted in the region since $1988[2,3,4]$. It only took three mailings to achieve the target return rate of 50\% in 2002, 2005, 2007, 2012 and 2015. Conversely, it took four mailing to achieve the 50\% return rate in 1988, 1993, 1998, 2010, 2017 and 2019.

Survey answers were coded and entered into Microsoft Excel. Missing data were excluded from the analysis. The data were analysed at two levels using SAS [16]. The first level of analysis generated frequencies, while the second level evaluated the impacts of demographic factors. Significance $(\mathrm{P}<0.05)$ to demographic factors was tested using a chi-square distribution $[15,16]$. Since similar response rates were observed in all survey years, data analysis procedures were identical for each sampling. The schematic for the methodology used in this study is shown in Table 1.

\section{RESULTS AND DISCUSSION}

The survey methodology was not designed to be unique, but rather to be able to compare resident responses over time so that useful information could be obtained. Using the mail-based Dillman survey methodology, response rates of over 50\% were achieved for all 11 surveys with three or 4 mailings. This high response rate resulted in a sampling error of less than 5\%. Approximately $4 \%$ of the data presented in this paper was previously published in studies about specific survey year information $[3,4]$. This paper is unique because the data evaluated 32-year trends in the PNW.

When this survey was first initiated in 1988, the population of the four PNW states was $8,696,000$ [17]. However, by 2019, the region's population had grown to $14,516,000$ [18]. This $16 \%$ population increase resulted in the region becoming more urban over the 32-year 
study period. On a numerical basis in 2019 based on county classification, the urban, suburban and rural populations of the four PNW states were 11,612,000, 2,322,000 and 584,000 people, respectively.

\subsection{Public perceived importance of water issues}

The perceived importance of the 13 following water related issues were followed using surveys between 1988 and 2019: (1) aquatic habitat, (2) bays and estuaries, (3) water for use in commerce, (4) drinking water, (5) groundwater, (6) water use by industry, (7) irrigation water for agriculture, (8) marine water, (9) water for power generation, (10) water for recreation, (11) rivers and lakes, (12) mountain snowpack and (13) protection of wetlands. The data is presented by looking at the percentage of public considering each water issue as very important (Table 2). The 32-year trends for these 13 water issues resulted in curves being flat for 6 water issues, trending higher for 6 issues and downwards for 1 water issue. Over the 32-year survey period, public importance was up for aquatic habitat, power generation, wetlands, rivers and lakes, mountain snowpack and recreation. Conversely, the 32-year trend was down importance-wise for irrigation use in agriculture. Significant differences comparing public importance in 1988 and 2019 were observed for aquatic habitat, water for industry, irrigation for agriculture, power generation, recreation, rivers and lakes, mountain snowpack and protection of wetlands (Table 2).

Table 2: The percentage of the public listing 13 different water-related issues as very important over a 32-year study based on 11 different surveys in the PNW, USA, between 1988 and 2019; over 10,210 surveys were completed by the public.

\begin{tabular}{lcclll}
\hline Water issue & 1988 & 2019 & $32-$ year trend & Significance & Significance \\
\cline { 2 - 6 } & $\%$ & $\%$ & & 1988 vs. 2019 & 2010 vs. 2019 \\
\hline Aquatic habitat & 70.1 & 74.2 & up 4\% & $* *$ & NS \\
Bays and estuaries & 52.9 & 51.6 & flat & NS & NS \\
Commerce & 19.4 & 18.2 & flat & NS & NS \\
Drinking water & 98.2 & 97.9 & flat & NS & NS \\
Groundwater & 93.4 & 94.8 & flat & NS & NS \\
Industry & 34.2 & 32.1 & flat & $* *$ & NS \\
Irrigation (agriculture) & 64.2 & 40.1 & down 24\% & $* * * *$ & $* * * *$ \\
Marine water & 61.8 & 60.2 & flat & NS & NS \\
Power generation & 60.8 & 69.4 & up 8\% & $* *$ & NS \\
Recreation & 22.5 & 49.3 & up 27\% & $* * * *$ & $* * *$ \\
Rivers/lakes & 81.2 & 95.2 & up 14\% & $* * *$ & $* *$ \\
Snowpack (mountain) & 52.4 & 89.1 & up 37\% & $* * * *$ & $* * *$ \\
Wetlands & 66.8 & 76.2 & up 9\% & $* * * *$ & $* *$ \\
\hline
\end{tabular}

$* *, * * *$ and $* * * *$ denote significance at $0.05,0.01$ and 0.001 level of probability, respectively. NS $=$ not significant. 
This survey provided a wealth of important data. Four water issues (mountain snowpack, irrigation for agriculture, water for recreation and wetland protection) were selected for a graphic display showing data points for each of the 11 survey years (Figure 1). The four selected water issues demonstrate differences in public views over time. In 1988, only $52.4 \%$ of the public considered mountain snowpack as a very important issue; however, by 2019, over $89.1 \%$ of the public considered this a very important issue. In the span of the 32-year survey period, the percentage of people saying that the snowpack was important increased by $37 \%$. When public views were compared in 1988 with 2019, significant differences were found (Table 2, Figure 1). This observation is probably related to media coverage that keeps reminding the public that snowpack is related to many water issues - such as irrigation water availability, water for commerce and industry, groundwater quantity and water for power generation.

Public views of the use of irrigation water for agriculture as being very important declined from $64.2 \%$ in 1988 to $40.1 \%$ in 2019 . This decline would have been expected since the public in the PNW has become significantly more urban in the last 32 years. Conversely, water for recreation has become much more important in the last 32 years $(22.5 \%$ very important in 1988 vs. $49.3 \%$ in 2019). The public has generally considered wetland protection to be very important in the last 32 years; however, the survey trend shows that its importance has increased by over $9 \%$ since 1988 (Figure 1).

When the 13 water issues are compared as being very important to the public, ranking them from the most important to least important was as follows: (1) drinking water, (2) groundwater, (3) rivers and lakes, (4) aquatic habitat, (5) wetlands, (6) mountain snowpack, (7) power generation, (8) marine water, (9) irrigation water for agriculture, (10) bays and estuaries, (11) water for recreation, (12) water for industry and (13) water for commerce (Table 3). It makes sense that drinking water was rated the highest - because all citizens need it. Conversely, bays and estuaries and marine water ranked lower because a significant portion of the regions' population is more than $100 \mathrm{~km}$ from the coastline.

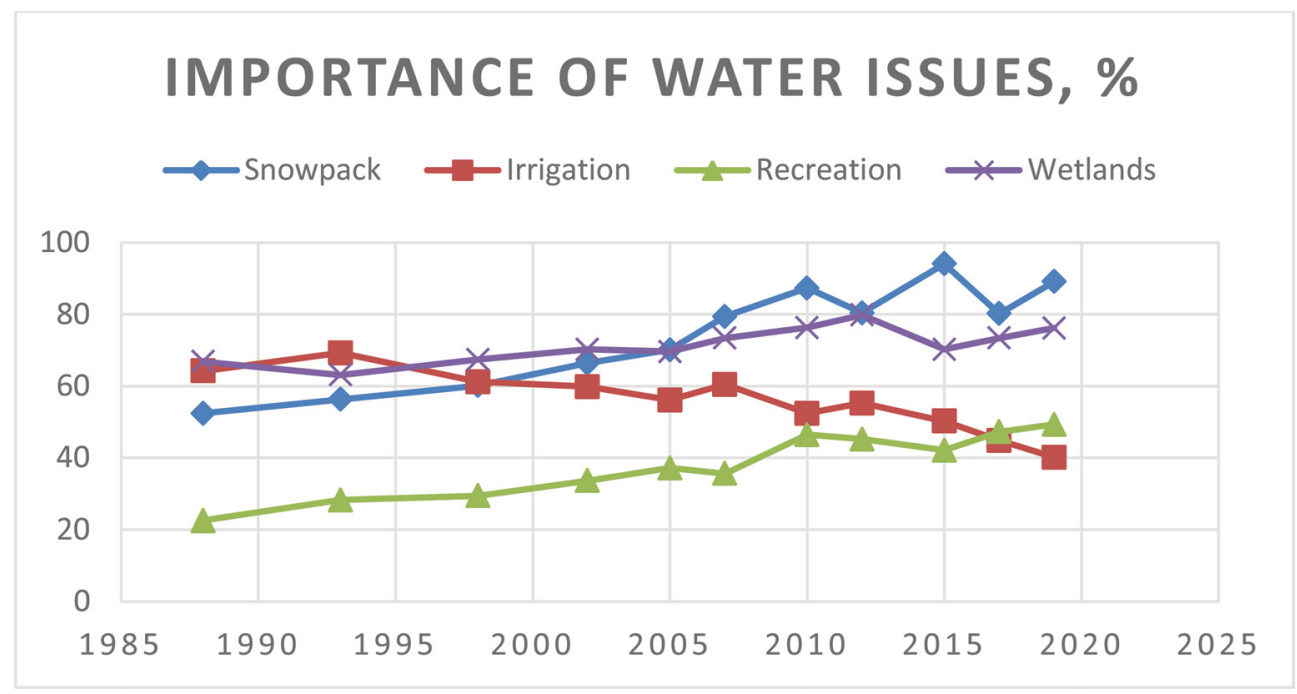

Figure 1: Public perception of mountain snowpack, irrigation water for agriculture, water for recreation and wetland preservation as being very important between 1988 and 2019 based on survey conducted in the PNW, USA. 
Table 3: Ranking the water issues from most important (rank \#1) to least important (rank \#13) surveyed in the PNW based on public perception of each issue as very important; over 10,210 surveys were completed by the public.

\begin{tabular}{llll}
\hline Water issue & 1988 rank & 2019 rank & Overall rank \\
\hline Aquatic habitat & 4 & 6 & 4 \\
Bays and estuaries & 9 & 9 & 10 \\
Commerce & 13 & 13 & 13 \\
Drinking water & 1 & 1 & 1 \\
Groundwater & 2 & 3 & 2 \\
Industry & 11 & 12 & 12 \\
Irrigation (agriculture) & 6 & 11 & 9 \\
Marine water & 7 & 8 & 8 \\
Power generation & 8 & 7 & 7 \\
Recreation & 12 & 10 & 11 \\
Rivers/lakes & 3 & 2 & 3 \\
Snowpack (mountain) & 10 & 4 & 6 \\
Wetlands & 5 & 5 & 5 \\
\hline
\end{tabular}

\subsection{Voluntary actions taken to protect water quality}

PNW residents were asked about their use of four different voluntary actions they took to protect water quality between 1988 and 2019. The voluntary actions were pooled, and the results are shown in Figure 2. Voluntary actions to protect water quality were initially practiced by $16.2 \%$ of the public in 1988 ; however, by 2019 , over $72 \%$ of the public reported taking these proactive actions. The trend was upwards as four times as many people took voluntary actions in 2019 compared with 1988. Initially in 1988, 12.3, 9.6 and $16.2 \%$ of survey respondents changed home waste disposal, changed fertilizer/pesticide use and changed motor oil disposal, respectively. However, by 2019, these percentages increased to 60.7, 58.2 and $60.2 \%$

The percentage of the public not taking proactive voluntary actions to protect water quality was $59.2 \%$ in $1988,17.4 \%$ in 2010 and only $7.8 \%$ in 2019 (Table 4). Educational programs developed to use voluntary actions to protect water quality were successful because by 2019 over $90 \%$ of the surveyed public were taking at least one voluntary action. Over time, statistically more residents were using voluntary actions to make the water resource more sustainable (1988 vs. 2019 and 2010 vs. 2019).

Demographic differences had a significant impact on responses to taking voluntary actions (Table 5). All evaluated demographic factors (gender, age, education level, community size, state of residence and county population) showed significant differences in actions taken by the public. The characteristics of people most likely to proactively address water quality were females, between the ages of 40 and 50,2+ years of college, communities of greater than 100,000, residents of Washington and Oregon, and residents of urban counties (Table 5). 


\section{Actions to protect water quality, \%}

16.2

19.4

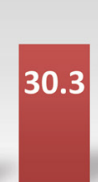

40.3
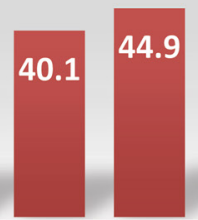

48.4

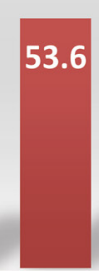

63.6

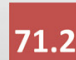

19881993

1998

2002

2005

2007

2010

20122015

20172019

Figure 2: Percent of survey respondents that took at least one voluntary action to protect water quality based on PNW survey results between 1988 and 2019.

Table 4: Voluntary actions taken by the public to protect water quality in the PNW based on survey data collected in 1988, 2010 and 2019 as reported by survey data.

\begin{tabular}{lccccc}
\hline Action & 1988 & 2010 & 2019 & 1988 vs. 2019 & 2010 vs. 2019 \\
\cline { 2 - 6 } & $-----------\%$ & --------- & \multicolumn{2}{c}{ Significance } \\
\hline $\begin{array}{l}\text { Changed home waste } \\
\text { disposal }\end{array}$ & 60.7 & 12.3 & 58.2 & $* * * *$ & NS \\
$\begin{array}{l}\text { Changed pesticide/ } \\
\text { fertilizer use }\end{array}$ & 9.6 & 47.4 & 58.2 & $* * * *$ & $* *$ \\
$\begin{array}{l}\text { Changed use to protect } \\
\text { groundwater }\end{array}$ & 6.1 & 26.3 & 47.1 & $* * * *$ & $* * *$ \\
$\begin{array}{l}\text { Changed motor oil } \\
\text { disposal }\end{array}$ & 16.2 & 64.2 & 60.2 & $* * * *$ & NS \\
No actions taken & 59.2 & 17.4 & 7.8 & $* * * *$ & $* *$ \\
\hline
\end{tabular}

$* *$ and $* * * *$ denote significance at 0.5 and 0.001 level of probability, respectively. NS $=$ not significant.

\subsection{Voluntary actions taken to protect water quantity (save water)}

PNW residents were asked about their use of four different voluntary actions they used to protect water quantity (save water) between 1988 and 2019. The voluntary actions were pooled and results are shown in Figure 3. Voluntary actions to protect water quantity were initially practiced by $21.6 \%$ of the public in 1988 ; however, by 2019 , over $91 \%$ of the public reported taking these proactive actions. The trend was upwards as four times as many people had taken voluntary actions in 2019 compared with 1988. Initially in 1988, 34.8, 20.4, 15.1 and $20.0 \%$ of survey respondents had installed water-saving devices, changed yard watering, 
Table 5: Influence of population demographics on the actions taken by citizens to protect water quality; all survey years are pooled.

\begin{tabular}{lll}
\hline Demographic & Highest action rate & Significance \\
\hline Gender & Females & $* *$ \\
Age & 40 to 50 years old & $* * *$ \\
Education level & $2+$ years of college & $* * *$ \\
Community size & $>100,000$ people & $* * * *$ \\
State of residence & Washington, Oregon & $* * *$ \\
County status & Urban & $* * *$ \\
\hline
\end{tabular}

$* *, * * *$ and $* * * *$ denote significance at $0.05,0.01$ and 0.001 level of probability, respectively. NS $=$ not significant.

\section{Actions to protect water quantity, \%}

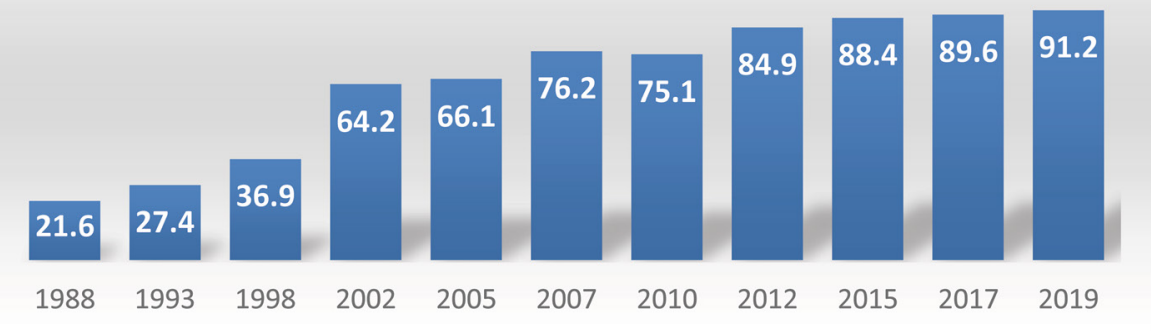

Figure 3: Percent of survey respondents that took at least one voluntary action to protect water quantity (water resources) based on PNW survey results between 1988 and 2019.

changed household water use and changed the way they washed their vehicles, respectively (Table 6). However, by 2019, these percentages increased to 78.2, 58.4, 67.2 and 34.9\%.

The percentage of the public not taking proactive voluntary actions to protect water quantity was $36.4 \%$ in $1988,19.9 \%$ in 2010 and only $9.4 \%$ in 2019 (Table 6). Educational programs developed to use voluntary actions to save water were successful because by 2019 over $90 \%$ of the survey public were taking at least one voluntary action. Over time, statistically more residents were using voluntary actions to make the water resource more sustainable (1988 vs. 2019 and 2010 vs. 2019).

Demographic differences had a significant impact on responses to taking voluntary actions to save water (Table 7). All evaluated demographic factors (gender, age, education level, community size, state of residence and county population) showed significant differences in actions taken by the public over this 32-year study period. The characteristics of people most likely to proactively address water quantity were females, citizens less than 30 years old, 2+ years of college, communities of greater than 100,000, residents of Washington and residents of urban counties (Table 7). 
Table 6: Voluntary actions taken by the public to protect water quantity in the PNW based on survey data collected in 1988, 2010 and 2019 as reported by survey data.

\begin{tabular}{|c|c|c|c|c|c|}
\hline \multirow[t]{2}{*}{ Action } & 1988 & 2010 & 2019 & 1988 vs. 2019 & 2010 vs. 2019 \\
\hline & \multicolumn{3}{|c|}{--o- } & \multicolumn{2}{|c|}{ Significance } \\
\hline Installed water-saving device & 34.8 & 60.3 & 78.2 & $* * * *$ & $* * * *$ \\
\hline Changed yard watering & 20.4 & 46.9 & 58.4 & $* * * *$ & $* * * *$ \\
\hline Changed household water use & 15.1 & 49.4 & 67.2 & $* * * *$ & $* * * *$ \\
\hline Changed vehicle washing & 20.0 & 34.2 & 34.9 & $* * * *$ & NS \\
\hline No actions taken & 36.4 & 19.9 & 9.4 & $* * * *$ & $* * * *$ \\
\hline
\end{tabular}

**** denotes significance at 0.001 level of probability. NS $=$ not significant.

Table 7: Influence of population demographics on the actions taken by citizens to protect water quantity; all survey years are pooled.

\begin{tabular}{lll}
\hline Demographic & Highest action rate & Significance \\
\hline Gender & Females & $* * *$ \\
Age & $<30$ years old & $* * *$ \\
Education level & $2+$ years of college & $* * *$ \\
Community size & $>100,000$ people & $* * *$ \\
State of residence & Washington & $* *$ \\
County status & Urban & $* * *$ \\
\hline
\end{tabular}

** and *** denote significance at 0.05 and 0.001 level of probability, respectively. NS $=$ not significant.

\section{CONCLUSIONS AND RECOMMENDATIONS}

The views of the surveyed public over this 32-year survey study changed over time. The per cent of the public viewing different water issues as very important increased from 1988 to 2019 for mountain snowpack (up 37\%), water for recreation $(27 \%$ ), clean rivers and lakes $(14 \%)$, wetland protection $(9 \%)$, water for power generation $(8 \%)$ and aquatic habitat $(4 \%)$. Conversely, fewer survey respondents considered irrigation water for agriculture a very important issue in 2019 compared with 1988 (down 24\%). Public opinion about bays and estuaries, drinking water, water for commerce, water for industry, groundwater and marine water did not significantly change over the 32-year period.

Other major findings of this 32-year survey study were as follows:

- Compared with 1988 , over $72 \%$ of the surveyed respondents took one or more actions to protect water quality by 2019 such as changing home waste disposal, changing the use of fertilizers and pesticides and changing used motor oil disposal.

- Compared with the data initially collected in 1988, over $92 \%$ of the surveyed respondents undertook at least one voluntary action to address water quantity (saving water) such as installing in-home water-saving devices, reducing water use in the home and/or reducing water use in the yard by 2019 . 
- Media campaigns by environmental agencies, non-government organizations and universities successfully educated the public about voluntary actions to address water resource issues; These media campaigns and education outreach are largely responsible for the public voluntary investment in water resource improvement in the region.

- This collected data should be used by educators, scientists and public health officials to determine the appropriate outreach methods that should be used to accurately pair public perceptions with scientific facts within the PNW.

The major limitations of this this study were that: (1) it was dependent on the people completing the surveys actually being representative of the population in the PNW, (2) the interpretation of the survey questions by the public did not change over time, (3) and the actual survey questions were adequate barometers of individuals protecting both water quality and water resources (quantity). The first two potential limitations were at least partially negated by using the Dillman survey methodology, which has been widely used in these types of studies. It is important that this survey study continues over the next 20 years to understand how the public views of voluntary actions to protect water change with time. If, over time, less people take voluntary actions educational programs may need to be modified to address this change. Finally, this study should continue because it is the largest long-term study of its kind tracking voluntary actions.

\section{ACKNOWLEDGEMENTS}

We would like to acknowledge USDA-NIFA for their support, project 2008-51130-04734.

\section{REFERENCES}

[1] Arnell, N.W., van Vuuren, D.P. \& Isaac, M., The implications of climate policy for the impacts of climate change on global water resources. Global Environmental Change, 21, pp. 592-603, 2011. doi:http://dx.doi.org/10.1016/j.gloenvcha.2011.01.015.

[2] Postel, S.L., Daily, G.C. \& Ehrlich, P.R., Human appropriation of renewable fresh water. Science, 271, pp. 785-788, 1996. doi: http://dx.doi.org/10.1126/science.271.5250.785.

[3] Mahler, R. L., Simmons, R., Sorensen, F., \& Miner, J.R., Priority water issues in the Pacific Northwest, Journal of Extension [On-line], Vol 42(5). Article 5RIB3. 2004. Available at: http://www.joe.org/joe/2004october/rb3.php 2004.

[4] Mahler, R.L. \& M.E. Barber., Using adult education to improve the sustainability of water resources in the Pacific Northwest, USA. International Journal of Sustainable Development and Planning. 2015, Vol 10(6):828-842. 2015. DOI:10.2495/SDP-V10N6-828-842.

[5] Worldometers.info. Human populations and projections by country. Worldometers.info. Accessed 16 February 2021.

[6] Currell, M.J., Han, D., Chen, Z. \& Cartwright, I., Sustainability of ground water usage in northern China: dependence on paleowaters and effects on water quality, quantity and ecosystem health. Hydrologic Processes, 26, pp. 4050-4066, 2012. doi: http:// dx.doi.org/10.1002/ hyp.9208.

[7] Liu, ,J. \& W. Yang' Water sustainability for China and beyond. Science,337(6095), pp.649-650, 2012. DOI: 10.1126/science 1219471; available at: hhtp://www.sciencemag.org/con- tent/337/6095/649.full.

[8] Chinese Academy of Sciences, China Sustainable Development Strategy Report 2007 - Water: Governance and Innovation, Science Press: Beijing, 2007. 
[9] Anonymous, Voluntary action needed to protect water quality. Journal of Environmental Health, 53(2) 6, pp, 1990.

[10] May, P.J., Marine facilities and water quality: regulatory versus voluntary approaches. Coastal Management, 31, pp. 297-317, 2003. doi: http://dx.doi. org/10.1080/08920750390233009.

[11] Neufield,D.A., An ecosystem approach for groundwater: the case of Waterloo Region, Ontario, Canada. Hydrogeology Journal, 8, pp. 239-250, 2000. doi: http://dx.doi. org/10.1007/pl00021536.

[12] Pumphrey, R.G., Edwards, J.A. \& Becker, K.G., Urban and rural attitudes toward municipal water controls: a study of a semi-arid region with limited water supplies. Ecological Economics, 65, pp. 1-12, 2008.

[13] Koski, C. \& May, P.J., Interest and implementation: fostering voluntary regulatory actions. Journal of Public Administration Research and Theory, 16, pp. 329-349, 2006. doi: http:// dx.doi.org/10.1093/jopart/mui048.

[14] Salent, P., \& Dillman, D., How to Conduct Your own Survey, John Wiley and Sons, Inc.: New York, New York, 1994.

[15] Dillman, D., Mail and Internet Surveys: The Tailored Design Method, John Wiley and Sons, Inc.: New York, New York, 2000.

[16] SAS Institute Inc., SAS Online Document 9.1.3. Cary, North Carolina: SAS Institute Inc., 2004.

[17] Wikipedia. 2021. List of states of the United States by population. Accessed January 2021.

[18] United States Bureau of the Census. 1988. Current population reports, Series P-25, No. 1017. Projection of the population of states by age, sex and race 1988 to 2010. U. S. Government Printing Office, Washington DC. 